NASA Technical Memorandum 89914

AlAA-87-9200

\title{
Regenerative Fuel Cell Study for Satellites in GEO Orbit
}

\author{
(MASA-TH-89914) GEGENERATIVE FUEL CELL \\ STODY POB SATELIITES IN GEC OREIT (NASA) 8 \\ F Avail: $\mathrm{TIS}$ EC $102 / \mathrm{AE}$ 101 CSCL 10B \\ N87-223 10 \\ Unclas \\ H1/44 0074230
}

Leslie Van Dine

International Fuel Cells

South Windsor, Connecticut

Olga Gonzalez-Sanabria

Lewis Research Center

Cleveland, Ohio

Alexander Levy

International Fuel Cells

South Windsor, Connecticut

Prepared for the

22nd Intersociety Energy Conversion Engineering Conference

cosponsored by the AIAA, ANS, ASME, SAE, IEEE, ACS, and AIChE

Philadelphia, Pennsylvania, August 10-14, 1987

\section{NMSn}




\section{ABSTRACT}

This paper summarizes the results of a 12 -month study to identify high performance regenerative hydrogen-oxygen fuel cell concepts for geosynchronous satellite application. Emphasis was placed on concepts with the potential for high energy density (watt-hours/lb) and passive means for water and heat management to maximize system reliabilicy.

Both polymer membrane and alkaiine electrolyte fuel cells were considered, with emphas is on the alkaline cell because of its high performance, advanced state of development and proven ability to operate in a launch and space environment.

Three alkaline system concepts were studied. The first, termed the integrated design utilized a configuration in which the fuel cell and electrolysis cells are alternately stacked inside a pressure vessel. Product water is transferred by diffusion during electrolysis operation and waste heat is conducted through the pressure vessel wall, thus using completely passive means for transfer and control.

The second alkaline system, referred to as the dedicated design, uses a separate fuel cell and electrolysis stack so that each unit can be optimized in size and weight based on its orbital operating period.

The third design was a reversible stack configuration, in which each individual cell can operate in both the fuel cell and electrolysis mode, thus eliminating the need for two separate stacks and associated equipment.

Results indicate that using near term technology energy densities between 46 and 52 watt-hours/lb can be achieved at efficiencies of 55 percent. Using advanced light weight cell construction which has been achieved in experimental cells, composite tankage material for the reactant gases and the reversible stack concept, system energy densities of 115 watt-hours/lb can be projected.

\section{Introduction}

The paper summarizes the results of a 12-month study performed by International Fuel Cells with the NASA Lewis Research Center. The primary objective of this study was to identify critical technology areas for regenerative H2-02 fuel cell systems which, if successfully developed could be competitive with advanced rechargeable batteries for geosynchronous (GEO) satellite missions.
While various cell types were studied, emphas is was placed on the alkaline cell because of its high performance, advanced state of development and proven ability to operate in $a$ launch and space environment.

Previous studies of regenerative fuel cell systems have indicated that due to the need for dynamic components necessary for thermal, reactant, and product control, the achievement of the reliability levels needed for unmanned missions of up to ten years requires a high degree of redundancy resulting in reduced energy density. Based on the need for high reliability and high specific energy density, a number of system concepts were studied which minimized the dynamic components, and emphasized passive means for product water and heat management and system control.

Two of the more promising alkaline system concepts are described in this paper. The first termed the integrated design utilizes a configuration in which the fuel cell and electrolysis cells are alternately stacked inside a pressure vessel, with passive means of heat and water transfer. This design, while non-conventional in terms of arrangement, utilizes state-of-the-art performance, materials and cell component configurations. The second concept is more electrochemically advanced in nature and assumes the use of a dual function cell stack, in which each individual cell can operate both in the fuel cell or electrolysis mode. This approach, which also uses passive means for control, results in the fewest number of cells required and has a potential for the highest reliability system. However, the technology for this system is not yet fully developed, but, as shown in this paper, warrants additional effort.

The mission requirements and performance goals were specified by NASA for GEO applications and are described in the table below:

Table I. Mission Requirement for GEO Applications

- MAX. REQ'D POWER, kW 25

- AVG. POWER, kW

- NOMINAL VOLTAGE AT DISCHARge, VOLTS 120

- CHARGE/DISCHARGE TIME RATIO, HRS/HRS 22.8/1.2

- DESIGN CYCLE LIFE

- DESIGN LIFE, YRS.

- DESIGN ENERGY STORAGE, W-HRS 30,000

- MODULE ENERGY DENSITY GOAL, W-HRS/LB. 50

- EFFICIENCY GOAL

- RELIABILITY UNMANNED 
The remainder of this paper covers the two selected systems in some detail with schematic drawings, component descriptions, assumed operating conditions and key assumptions. A weight summary is provided along with a preliminary conceptual design. In some cases parametric studies are included to establish the sensitivity of energy density to specific design changes. A final section is included which summarizes the results and outlines technology recommendations.

\section{Description of System Concept}

Figure 1 shows the basic elements of a regenerative fuel cell satellite energy storage system. During satellite eclipse periods the fuel cell electrochemically converts stored hydrogen and oxygen gas to produce d.c. power which is delivered to the main bus, while water, the product of the reaction is collected and stored as a liquid for later use. After the eclipse period, the solar panels provide power to the main bus as well as to an electrolysis unit. This unit dissociates the stored product water, refilling the reactant storage tanks with pressirized hydrogen and oxygen. Finally waste heat from the storage system, which is primarily produced in the fuel cell, is removed and ultimately rejected through a radiator.

\section{Integrated Alkaline System Description}

An integrated, H2-02 alkaline fuel cell/electrolyzer concept was selected as the preferred state-of-the-art configuration for the GEO design. The proposed system utilizes complete$1 y$ passive techniques for regenerative fuel cel1 operation and control.

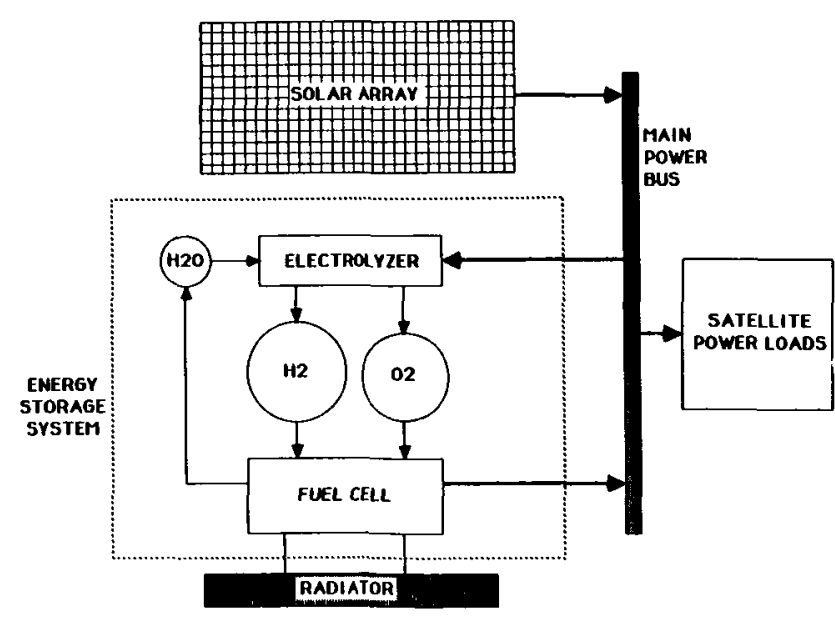

Figure 1. Satellite Energy Storage System

The basic fuel cell module for this concept produces $12.5 \mathrm{~kW}$ and consists of a hydrogen tank, an oxygen tank, and two integrated fuel cell - electrolyzer cell substacks as shown in Figure 2. The cell stack is arranged in two substacks to facilitate the series-parallel electrical connections required when switching from fuel cell to electrolys is operation to maintain near constant voltage output and input. Each stack utilizes annular fuel cell and electrolysis cells alternately stacked inside of a pressure vessel, as shown in Figure 3. During discharge, product water from the fuel cell reaction is stored in porous carbon reservoir plates. Passive water transport is achieved by diffusion from the fuel cell to the electrolysis cell. Waste heat is conducted to a graphite plate located between cell pairs and then conducted through the plane of the plate to the pressure vessel wall. This heat may be rejected from the vessel wall by a circulating coolant loop or by heat pipe type devices with their condensing sections attached to a space radiator or heat storage reservoir. During charge, (electrolysis operation) the water reactant is transferred from the porous carbon reservoir of the fuel cell by liquid and vapor diffusion to a porous plate in the electrolys is cell assembly.

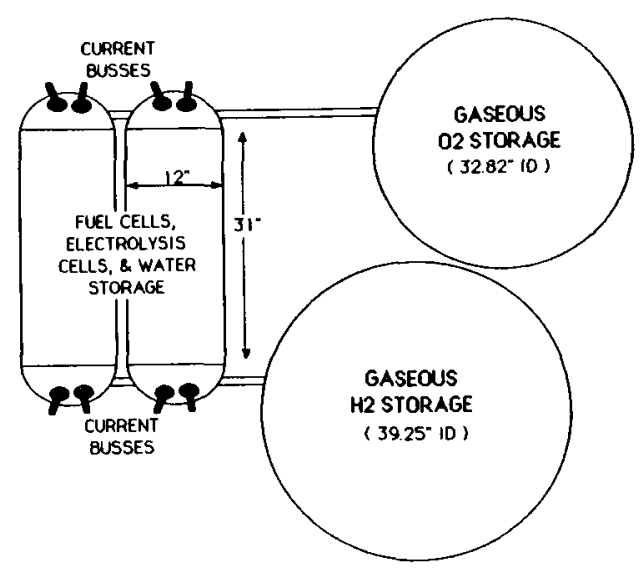

Figure 2. $12.5 \mathrm{~kW}$ Module For Energy Storage Geosynchronous Earth Orbit

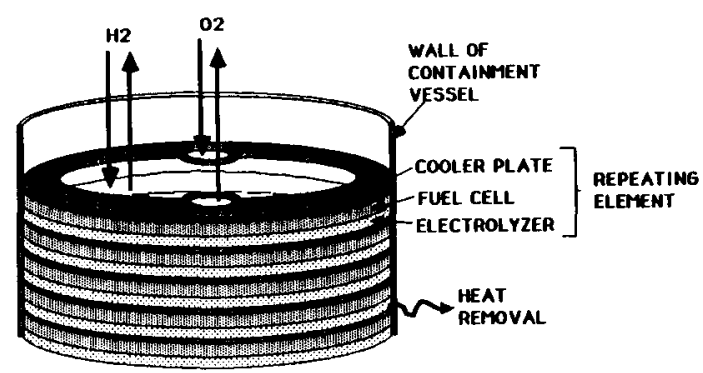

Figure 3, Cell Stack Cutaway Sketch

Current is collected at the cell edges and transferred by metallic pins located around the periphery of the plastic inner and outer cell frames. The atmosphere inside the pressure vessel is hydrogen which is connected directly to a hydrogen storage tank. Oxygen is fed and collected through manifolds molded into the inside edge frames of the annular cells and is connected to a separate oxygen storage tank (Figure 3).

The system is launched in the charged mode, with hydrogen and oxygen stored in the reactant tanks at full pressure, approximately 300 psia. 
Bootstrap startup is accomplished in a matter of minutes by feeding hydrogen and oxygen to the fuel cells. The waste heat generated by inefficiencies within the cell, plus heat supplied by electrical heaters fed from the fuel cell output, are used to raise the cell stack to operating temperature. During startup, heat rejection from the pressure vessel wall should be inhibited to minimize start-up time. The inner wall temperature of the cell stack pressure vessel and the reactant tanks is maintained above $156^{\circ} \mathrm{F}$ to prevent water condensation. During normal discharge operation reactant pressure decreases from 300 psia to 60 psia, and electrolyte concentration in the fuel cell decreases form 45 to 32 percent $\mathrm{KOH}$.

A11 the vesse1s are assumed to be metal. Both the containment vessel and hydrogen storage tank is Inconel 718, while the oxygen storage tank is 301 stainless.

\section{OPERATING CONDITIONS AND ASSUMPTIONS}

The technology assumptions and major design conditions used for this study are listed in Figure 4.

The fuel cell performance and life estimates are based on data from operation of the Orbiter fuel cell power plant and from testing of the NASA-Lewis advanced fuel cell configurations at IFC. Similar data for the electrolysis cell is based on information reported by Life Science, Inc. under contract NAS3-21287.

\begin{tabular}{|c|c|}
\hline & Bial \\
\hline - max. operating pressure, pSIa & 300 \\
\hline - MIN. OPERATING PRESSURE, PSIA & 60 \\
\hline - nominal operating temp., "F & 180 \\
\hline - PERFOPMANice BASIS & $\begin{array}{l}F / C \text { - ORBITER } \\
\text { E/C - LSI (LITERATURE) }\end{array}$ \\
\hline - EFFICIENCY $\bullet$ AVG. POWER, $\mathrm{B}$ & 55.0 \\
\hline - PAAASITE POWER, (X OF AVG. POWER) & \\
\hline FUEL CELL & 1.5 \\
\hline ELECTROLYSIS & .7 \\
\hline - LIFE, YRS (WEAR-OUT MODE) & 17 \\
\hline - POWER PLANT ARRANGEMENT & $\begin{array}{l}2 \times 12.5 \mathrm{KW} \text { Modules } \\
\text { (Spares as req'd) }\end{array}$ \\
\hline - NO. OF REACT ANT TAMK PAIRS PER MOOULE & 1 \\
\hline $\mathbf{U L E}$ & 2 \\
\hline
\end{tabular}

Figure 4. Design Conditions and Assumptions

For this design the operating temperature of $180^{\circ} \mathrm{F}$ and maximum operating pressure of 300 psia were chosen primarily because they are within the regime of operating experience, and allow existing models of performance and cell life to be reliably used. To date a fuel cell stack has demonstrated 18,000 hours of operation, while an electrolysis cell has run for over 30,000 hours, both in a cyclic mode. Analysis indicates that the primary wear-out mode of a fuel cell is the excessive conversion of the alkaline electrolyte from hydroxide to carbonate. In the proposed regenerative closed system, no carbonaceous gases will enter the cell from external reactants. Only the degradation of stack materials will cause carbonation. Using the materials presently being tested in fuel cells, a projected life of 150,000 hours is estimated before individual cell wear out occurs.

\section{CELL STACK SUMMARY}

Data relating to both fuel cell and electrolyzer cell stack performance and physical configuration are given in Figure 5.

For GEO applications, a high design current density was selected for the fuel cell to minimize hardware weight. For this application a constant power level was assumed. Charge time for the electrolysis cells is relatively long, 22.8 hours. This results in a low power requirement for charging, but since the electrolysis cells have the same active area as the fuel cells they can operate at very low current density. Significant resistance losses are allowed in the design of the electrolysis cells to generate sufficient waste heat to maintain the stacks at operating temperature during the long charge period.

\begin{tabular}{|c|c|}
\hline & GEO \\
\hline - STACK EOL" GAOSS PEAK POWER RATING (KW) & 6.34 \\
\hline - FUEL CELL EOL AVG DOWER CELL VOL TAGE & .04 \\
\hline - FUEL CELL AVERAGE CURPENT DENSITY, ASF & 340 \\
\hline - electrol yzer eo cell voutage & 1.5 \\
\hline - ELECTROYYZER CUREENT DENSITY, ASF & 18 \\
\hline - CELL AREA, fT2 & 31 \\
\hline - NO. OF CELLS PER STACK & 71 \\
\hline - NO. Of ELECTROYSIS CELLS PER STACK & 7 \\
\hline - TOTNA STACK HEIGHT, IN & 31 \\
\hline - INSIDE DINTETER OF STACK, IN. & 8.2 \\
\hline - OUTSIDE DIAMETER OF STACK, IN & 12.1 \\
\hline - PRESSURE VESSEL MATERIN & INCONEL 718 \\
\hline - PRESSURE VESSEL THICKNESS, IN. & .027 \\
\hline - heat revection & CONOUCTION TO VESSEL WALL \\
\hline - CURAENT COLLECTION & METNL PINS IN EOGE FRANE \\
\hline
\end{tabular}

Figure 5. Cell Stack Summary

The cell stacks are placed in a pressure vessel in which the atmosphere is hydrogen, thus no hydrogen manifolding is required. Oxygen, however, is manifolded through the inner plastic frame area of the cells. The oxygen manifolds and the oxygen compartments in the cell stack must be separated from the hydrogen by elastomer seals. The pressure differential between the two gases is slight, with the oxygen pressure being designed to be slightly above the hydrogen. Any leakage of oxygen into the hydrogen gas will be converted to water on the electrode catalyst and recycled into the system.

Figure 6 is a cutaway view of a single cell repeating element for the GEO cell stack. Each element includes a fuel cell, an electrolysis cell and a graphite cooling plate. The total thickness of each cooler plate/fuel cell/electrolyzer assembly is 0.44 inches, with the majority of this space taken up by a porous carbon plate which contains electrolyte and stored water. The heat, generated primarily 
during the discharge mode, is conducted to the cooler plate and then along the plane of the plate to the pressure vessel wall. The cooler plate is electrically insulated from the cell stack by thin Teflon sheets. The maximum temperature differential between the vessel outer wall and the hottest point in the cell is $35^{\circ} \mathrm{F}$ at the peak discharge power condition.

During the charge (electrolysis) mode, water must diffuse through the porous carbon plates containing electrolyte and across a hydrogen gas barrier separating the fuel cell from the electrolysis cell. Calculations have been made to show that the rate of water diffusion can easily support the design current levels in the electrolys is cell.

Current is conducted to the edge of the cells and transferred, in series, to the adjacent cells by means of metallic pins located in the plastic edge frames and spaced around the periphery of the cells. The fuel cell current transfer is through the inner frame, while that for the electrolysis cell is in the outer frame.
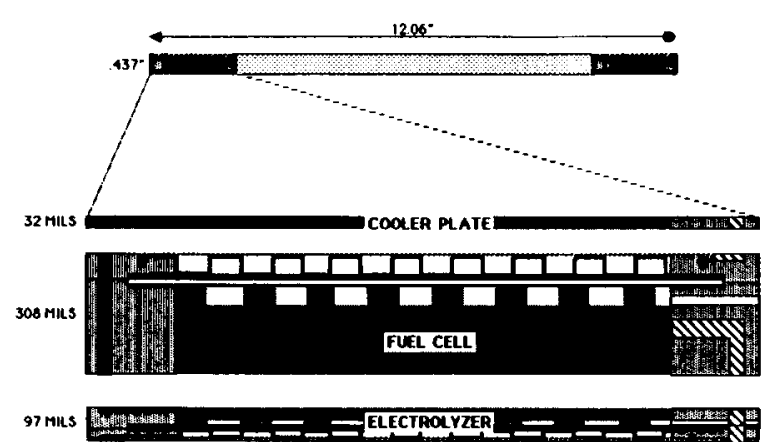

Figure 6. $12.5 \mathrm{~kW}$ GEO System Repeating Cel1 Element

\section{WE IGHT AND VOLUME SUMMARY}

A weight and volume summary for the satellite application is shown in Figure 7. As can be seen, the cell stack weights represent over 58 percent of the total. This fact points out the importance of developing lightweight, corrosion resistant materials of construction and also of increasing cell performance. Higher operating pressure, and temperature prove beneficial as discussed later in this paper.

The fuel cell weight is about a factor of three heavier than the electrolysis cells because the product water is stored in the fuel cell portion of the stack, and the vast majority of waste heat is generated in and must be removed from the fuel cell. If the graphite cooler plates could be eliminated, and the waste heat carried to the pressure vessel wall by the remaining fuel cell elements, a weight reduction of about 10 percent could be effected, and the cell stack length shortened by 17 percent. This design approach merits study for future work.

As indicated, a miscellaneous weight value of 10 percent was included to account for piping support structure, bellows, electric heaters, and current take-offs which were not specifically designed during this study.

The module equipment volume tabulated in Figure 7 represents the volume of all equipment but does not account for a packaging factor which will depend on layout and weight distribution requirements for the satellite.

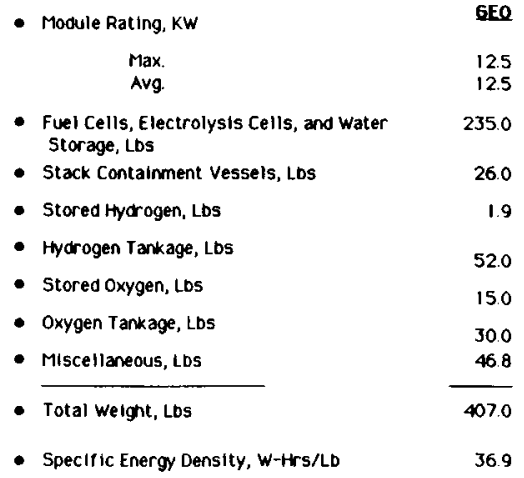

Figure 7. Weight Summary - Single Module

\section{EFFECT OF PRESSURE}

The benefit of high pressure operation on system weights comes from the significant advantage of using composite versus all metal construction for reactant and stack containment tankage. Figure 8 shows that operating the system at a pressure of 1800 psia and using composite materials for all pressure vessels results in a significant weight advantage over the 300 psia baseline system which uses all metal construction.

From Figure 8 it can be seen that at a system efficiency of $55 \%$, all the reactant hydrogen can be stored within the fuel cell containment vessel. At an efficiency of $60 \%$ both reactants can be stored within the containment vessel, thus not only eliminating the reactant tankage volume, but also, the complexity associated with feeding the reactants to the fuel cell and the structural penetrations required.

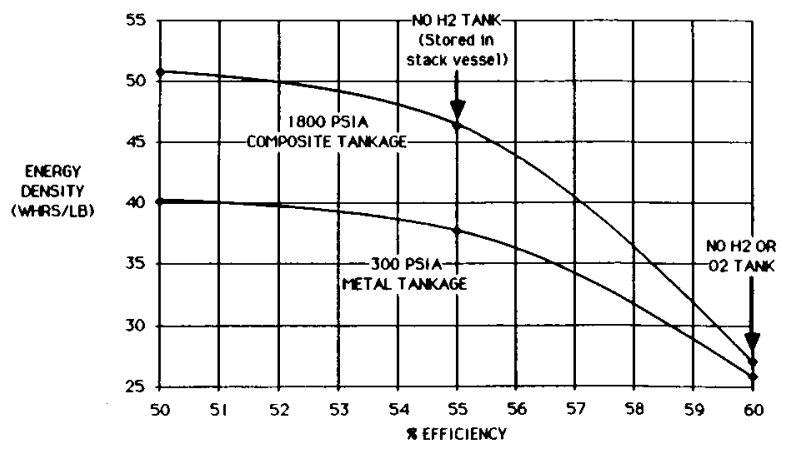

Figure 8. Effect of Pressure on Energy Density Variable Efficiency 
Higher pressure also significantly reduces the energy storage system volume. Figure 9 shows an 1800 psia system option resulting in $1 / 5$ the volume of the 300 psia system.

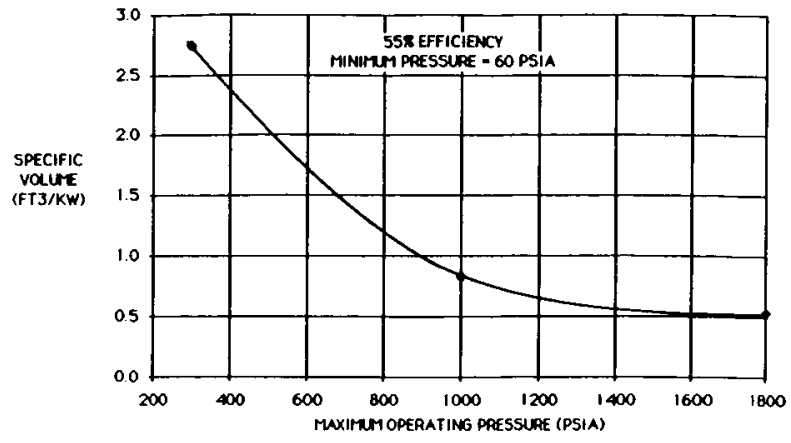

Figure 9. System Volume vs. Maximum Operating Pressure

\section{EFFECT OF TEMPERATURE}

Figure 10 shows the effect of cell stack temperature on the energy density for the GEO application. Significant improvements in the system's energy density may be possible if the fuel cell operating temperatures could be raised from the baseline condition of $180^{\circ} \mathrm{F}$ to $300^{\circ} \mathrm{F}$ or higher. The temperature effect is shown for both a 300 psia maximum operating pressure using metal reactant gas tankage and for an 1800 psia case with composite tankage. The combination of composite materials and relatively high cell temperature could result in system energy densities greater than the 50 Whrs/lb. goal.

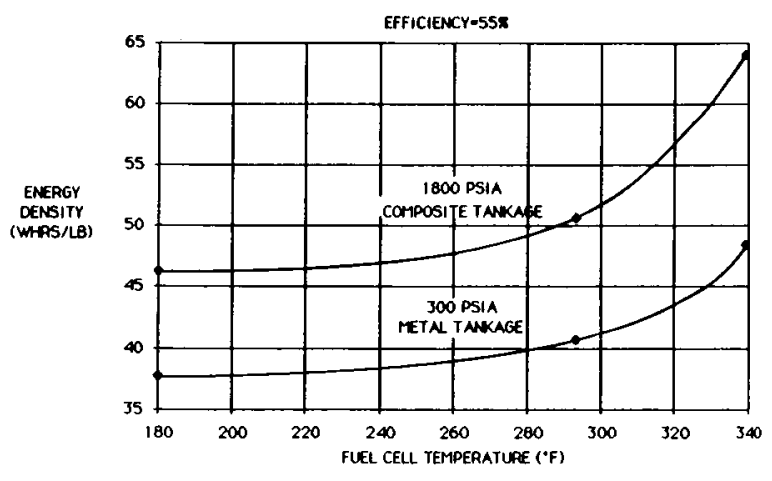

Figure 10. Effect of Temperature on Energy Density

\section{DUAL FUNCTION ALKALINE SYSTEM DESCRIPTION}

The dual function system is an integrated alkaline stack concept in which each single cell functions as both a fue 1 cell and an electrolysis cell. This approach has the potential for achieving a number of system advantages. Primarily, product water storage and transfer are minimized. Secondly, the number of cells and associated system components is reduced, thus providing a potentially high reliability system. Thirdly, if a dual function cell could be developed, with high performance, system weight and energy density would be very attractive for satellite applications.

To date, the difficulty in developing a system of this type is the incompatibility of high performance fuel cell oxygen electrode catalysts, when operating in the electrolysis mode. Most fuel cell catalysts are not stable at potentials of interest during electrolysis operation. Electrolysis oxygen catalysts operate poorly in the fuel cell mode. Therefore, the synthesis of an oxygen catalyst with stability and reasonable performance during both modes of operation would be a highly desirable goal.

Figure 11 illustrates the cell stack arrangement which has been used as a model for this study. The reactant gases are manifolded through passages located in the edge seal area of the circular stack. The current collection is now bipolar since each cell acts in a reversible fashion. This is a distinct advantage over the edge current collection of the integrated system described earlier. Heat removal in this stack is through the wall of the pressure vessel, however, flat circular heat pipes have been assumed to carry the heat radially rather than graphite plates. These heat pipes are placed every 5 cells and are electrically insulated from the pressure vessel wall to prevent shorting.

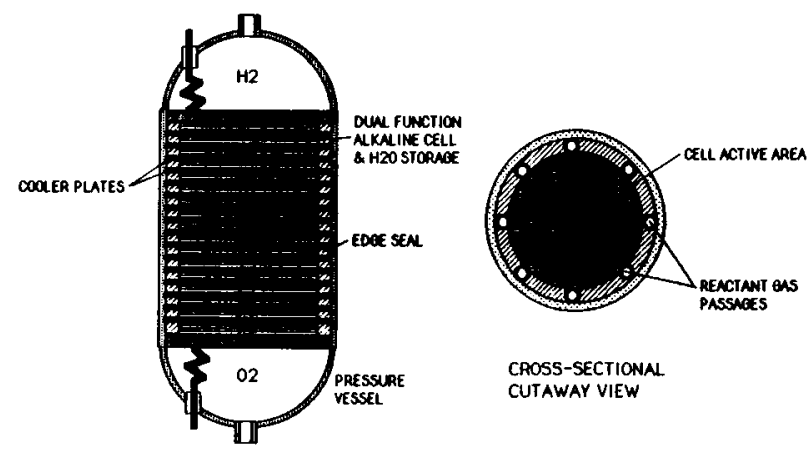

Figure 11. Dual Function Alkaline Ce11 Stack

Parametric Analys is of Dual Function System

Figure 12 shows the variation of specific energy density of a dual function alkaline energy storage system as a function of the cell and cooler specific weight (lbs/ft ${ }^{2}$ ) for three system options :

1. An 1800 psia system with composite H2, 02 and stack tankage.

2. An 1800 psia system with composite H2, 02 tankage and metal stack tankage.

3. A 300 psia system with all metal H2, $\mathrm{O} 2$ and stack tankage.

These systems were designed for a $55 \%$ efficiency and assumed that the dual function cell had the same performance as a dedicated alkaline fuel cell. 


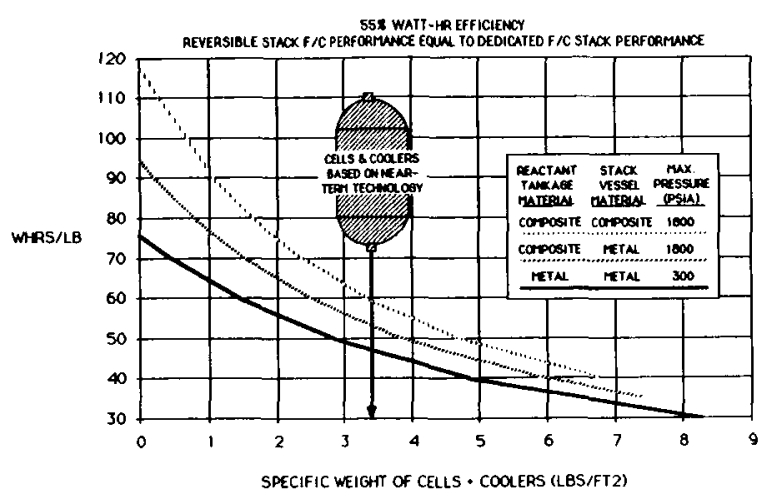

Figure 12. Dual Function Alkaline Energy Storage Systems System Specific Energy vs. Cell/Cooler Specific Weight

Overlayed on this chart is the estimated specific weight of $3.4 \mathrm{lbs} / \mathrm{ft}^{2}$ for cells and coolers of a dual function system using component designs based on near term technology. The figure shows that for this design, both high pressure options ( 1 and 2 ) exceeded the specific energy goal of 50 watt-hrs/lb and the all metal tankage option (3) falls just below the goal. The figure also shows that if present efforts are successful at reducing the weight of the cell and cooler components to $1 \mathrm{lbs} / \mathrm{ft}^{2}$ system specific energies densities approaching 100 watt-hrs/lb are achievable.

\section{Study Results}

The major results are shown in Figure 13 which depicts the energy density for each option described in this paper. The analys is was done for an overall system efficiency of $55 \%$ with the satellite in a geosynchronous orbit. The major conclusions that can be drawn from this study are as follows:

The regenerable systems studied indicate that energy densities competitive with advanced batteries are possible, with the use of relatively near term technology. Extrapolation of advanced alkaline regenerable systems show a potential improvement in energy density by approximately a factor of two.

Raising the storage pressure from 300 psia to 1800 psia and using 6061-T6 aluminum liner overwrapped with carbon epoxy composite material for all tankage, results in an energy densities increase to 46.0 Whrs/lb or a gain over low pressure storage of 23 percent.

High pressure storage of reactants has a dramatic effect on system specific volume. Increasing pressure from 300 to $1800 \mathrm{psia}$

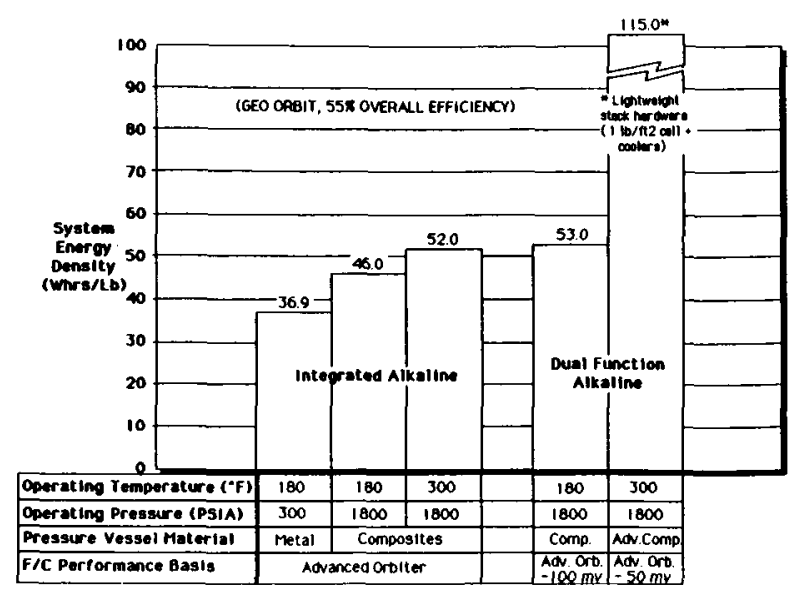

Figure 13. Energy Density Results for Systems Studied

reduces module specific volume from 2.75 $\mathrm{ft}^{3} / \mathrm{kW}$ to $0.51 \mathrm{ft}^{3} / \mathrm{kW}$ for the integrated alkaline system.

For the integrated system, if both pressure and temperature are increased (from 300 to 1800 psia and from $180^{\circ} \mathrm{F}$ to $300^{\circ} \mathrm{F}$ ) the specific energy density increases to $52 \mathrm{~W}$-hrs/lb., or an increase of 41 percent over the baseline design ( $36.9 \mathrm{~W}$-hrs/1b) .

The most attractive option utilizes dual function cells. As shown in Figure 13, even if the fuel cell performance is reduced by $100 \mathrm{MV}$ from present levels, the system specific energy would be 53.0 Whrs/lb. At the present time programs are under way to reduce the specific weight of alkaline cells. Designs as low as $0.34 \mathrm{lbs} / \mathrm{ft}^{2}$ have been conceived. A reasonable assumption is that a portion of these improvements can be incorporated into a satellite power plant design, such that the fuel cell and cooler specific weight can be reduced from $3.4 \mathrm{lbs} / \mathrm{ft}^{2}$ to $1.0 \mathrm{lb} / \mathrm{ft}^{2}$. In addition lighter weight composites are being developed for pressure vessels using ultra thin welded metal liners. If the performance loss in the fuel cell mode can be held to 50 MV below present performance and cell temperature increased to $300^{\circ} \mathrm{F}$, a specific energy density of $115 \mathrm{~W}$-hrs/1b. is predicted.

The dual function system holds the greatest potential for a high reliability. This approach results in the need for the fewest number of cells, which, for a passive system, tends to substantially increase reliability. 


\begin{tabular}{|c|c|c|c|}
\hline $\begin{array}{l}\text { 1. Report No. NASA TM-89914 } \\
\text { AIAA-87-9200 }\end{array}$ & 2. Government Accession No. & \multicolumn{2}{|c|}{ 3. Recipient's Catalog No. } \\
\hline \multirow{2}{*}{\multicolumn{2}{|c|}{$\begin{array}{l}\text { 4. Title and Subtitle } \\
\text { Regenerative Fue } 1 \text { Cell Study for Satellites } \\
\text { in GEO Orbit }\end{array}$}} & \multicolumn{2}{|l|}{ 5. Report Date } \\
\hline & & \multicolumn{2}{|c|}{$\begin{array}{l}\text { 6. Performing Organization Code } \\
506-41-21\end{array}$} \\
\hline \multirow{3}{*}{\multicolumn{2}{|c|}{$\begin{array}{l}\text { 7. Author(s) } \\
\text { Leslie Van Dine, Olga Gonzalez-Sanabria and } \\
\text { Alexander Levy }\end{array}$}} & \multirow{2}{*}{\multicolumn{2}{|c|}{$\begin{array}{l}\text { 8. Performing Organization Report No. } \\
\text { E-3607 }\end{array}$}} \\
\hline & & & \\
\hline & & \multicolumn{2}{|l|}{ 10. Work Unit No. } \\
\hline \multicolumn{2}{|c|}{ 9. Performing Organization Name and Address } & \multirow{2}{*}{\multicolumn{2}{|c|}{ 11. Contract or Grant No. }} \\
\hline \multicolumn{2}{|c|}{$\begin{array}{l}\text { National Aeronautics and Space Administration } \\
\text { Lewis Research Center } \\
\text { Cleveland, Ohio } 44135\end{array}$} & & \\
\hline \multicolumn{2}{|l|}{ 12. Sponsoring Agency Name and Address } & \multicolumn{2}{|c|}{$\begin{array}{l}\text { 13. Type of Report and Period Covered } \\
\text { Technical Memorandum }\end{array}$} \\
\hline \multicolumn{2}{|c|}{$\begin{array}{l}\text { National Aeronautics and Space Administration } \\
\text { Washington, D.C. } 20546\end{array}$} & \multicolumn{2}{|c|}{ 14. Sponsoring Agency Code } \\
\hline \multicolumn{4}{|c|}{$\begin{array}{l}\text { 15. Supplementary Notes } \\
\text { Prepared for the } 22 \text { nd Intersociety Energy Conversion Engineering Conference, } \\
\text { cosponsored by the AIAA, ANS, ASME, SAE, IEEE, ACS, and AIChE, Philadelphia, } \\
\text { Pennsyivania, August 10-14, } 1987 \text {. Leslie Van Dine and Alexander Levy, both of } \\
\text { Internationai Fue } 1 \text { Cel1s, South Windsor, Connecticut } 06074 ; 01 \text { a Gonzalez- } \\
\text { Sanabria, NASA Lewis Research Center. }\end{array}$} \\
\hline \multicolumn{4}{|c|}{$\begin{array}{l}\text { 16. Abstract } \\
\text { This paper summarizes the results of a } 12 \text {-month study to identify high performance regenerative } \\
\text { hydrogen-oxygen fuel cell concepts for geosynchronous satellite application. Emphasis was placed on } \\
\text { concepts with the potential for high energy density (watt-hours/lb) and passive means for water and } \\
\text { heat management to maximize system reliability. Both polymer membrane and alkaline electrolyte fuel } \\
\text { cells were considered, with emphasis on the alkaline cell because of its high performance, advanced } \\
\text { state of development and proven ability to operate in a launch and space environment. Three alkaline } \\
\text { system concepts were studied. The first, termed the integrated design utilized a configuration in } \\
\text { which the fuel cell and electrolysis cells are alternately stacked inside a pressure vessel. Product } \\
\text { water is transferred by diffusion during electrolysis operation and waste heat is conducted through } \\
\text { the pressure vessel wall, thus using completely passive means for transfer and control. The second } \\
\text { alkaline system, referred to as the dedicated design, uses a separate fuel cell and electrolysis stack } \\
\text { so that each unit can be optimized in size and weight based on its orbital operating period. The } \\
\text { third design was a reversible stack configuration, in which each individual cell can operate in both } \\
\text { the fuel cell and electrolysis mode, thus eliminating the need for two separate stacks and associated } \\
\text { equipment. Results indicate that using near term technology energy densities between } 46 \text { and } 52 \text { watt- } \\
\text { hours/lb can be achieved at efficiencies of } 55 \text { percent. Using advanced } 1 \text { ight weight cell construction } \\
\text { which has been achieved in experimental cells, conposite tankage material for the reactant gases and } \\
\text { the reversible stack concept, system energy densities of } 115 \text { watt-hours/lb can be projected. }\end{array}$} \\
\hline 17. Key Words (Suggested by Author(s)) & \multicolumn{3}{|c|}{ 18. Distribution Statement } \\
\hline \multicolumn{2}{|c|}{$\begin{array}{l}\text { Regenerative fuel cells } \\
\text { Geosynchronous satellites } \\
\text { Energy storage }\end{array}$} & \multicolumn{2}{|c|}{ y 44} \\
\hline 19. Security Classif. (of this report) & . Security Classif. (of this page) & 21. No. of pages & 22. Price* \\
\hline Unclassified & Unclassifie & & \\
\hline
\end{tabular}

*For sale by the National Technical Information Service, Springfield, Virginia 22161 